\title{
NOVEL PATTERNS OF THE EPSTEIN-BARR NUCLEAR ANTIGEN (EBNA-1) V-VAL SUBTYPE IN EBV-ASSOCIATED NASOPHARYNGEAL CARCINOMA FROM VIETNAM
}

Thuan $\mathrm{LD}^{1}$, Kha ND ${ }^{2}$, Minh NT ${ }^{3}$, Thuy LHA ${ }^{1, *}$

${ }^{*}$ Corresponding Author: Thuy Le Huyen Ai, Ph.D., Associate Professor, Department of Pharmaceutical and Medical Biotechnology, Faculty of Biotechnology, Room 304, 97 Vo Van Tan Street, Ward 6, District 3, Ho Chi Minh City Open University, Ho Chi Minh City, Vietnam.

Tel: +84-905-784-471. E-mail: thuy.lha@ ou.edu.vn

\begin{abstract}
The Epstein-Barr nuclear antigen 1 (EBNA-1) gene, plays a key role in viral infection, immortalization, viral genome replication, transcription and maintenance, and is the frequently detected gene, protein in both latent and lytic stage of Epstein-Barr virus (EBV). Based on the amino acid at position 487, EBNA-1 was classified into five subtypes, including P-Ala, P-Thr, V-Val, V-Pro and V-Leu. In Vietnam, an Asian country with a high incidence, mortality rates of nasopharyngeal carcinoma (NPC), had limited research on the EBNA-1 variation. Therefore, the aim of the current study was to identify the pattern of the EBNA-1 V-Val subtype in Vietnamese NPC patients, for its value further applied in NPC patients. Fifty-eight NPC biopsy samples were collected from local patients, analyzed by nested-polymerase chain reaction (nested-PCR), sequencing and compared to a previous B95-8 prototype sequence. Four EBNA-1 subtypes, including V-Val (35/44, 79.55\%), P-Ala (2/44, 4.55\%), P-Thr (5/44, 11.36\%), and V-Leu $(2 / 44,4.55 \%)$, were observed in $44 / 58$ samples. The sequences of the $\mathrm{V}$-Val subtype were compared to the B95-8 prototype, resulting in five patterns, contained seven consensus changes, including five amino acid changes at positions $487,499,502,524,594$, and two silent changes at residues 520 and 553. Of these, four of five, patterns were identified as novel patterns of the $\mathrm{V}$-Val subtype, showing the different changes of amino acids at positions 492, 528, $529,553,585$ and 588 , by comparison with previous studies of V-Val EBNA-1. Those data suggested the profile of vari-
\end{abstract}

\footnotetext{
${ }^{1}$ Department of Pharmaceutical and Medical Biotechnology, Faculty of Biotechnology, Ho Chi Minh City Open University, Ho Chi Minh City, Vietnam

${ }^{2}$ Faculty of Biology and Biotechnology, University of Science, Vietnam National University of Ho Chi Minh City, Ho Chi Minh City, Vietnam

${ }^{3}$ Cho Ray Hospital, Ho Chi Minh City, Vietnam
}

ation patterns of the $E B N A-1$ gene, related to geographic distribution, in Vietnamese NPC patients.

Keywords: Epstein-Barr nuclear antigen (EBNA-1); Epstein-Barr virus (EBV); V-val; Variation.

\section{INTRODUCTION}

Epstein-Barr virus (EBV), a ubiquitous human gramma herpes virus, discovered in 1964 by Epstein and Barr, taxonomically identified as human herpes virus 4 , is an oncogenic virus causing many EBV-associated human malignancies, including Hodgkin's disease, gastric carcinoma, B-cell lymphomas, and nasopharyngeal carcinoma (NPC) [1-5]. Following the infection of EBV, it remains in two stages: latency, lytic or productive phase of the life cycle of EBV [6]. Many processes of the viral cycle was dependent on the Epstein-Barr nuclear antigen (EBNA-1). Epstein-Barr nuclear antigen 1, a 641 amino acid protein, is the only consistently detected viral protein in many human EBV-associated malignancies $[3,7,8]$. Epstein-Barr nuclear antigen 1 is essential for EBV immortalization, the maintenance, replication and transcription of EBV genome, segregate EBV episome at mitosis [4,9]. A high frequency of sequence substitutions was identified in the carboxyl terminal (residues 325-641) of EBNA-1, containing many functional domains: the dimerization domain (residues 501532 and 554-598), DNA binding domain (residues 459487) and the transactivation domain (residues 450-641) $[8,10-12]$. Sequence variants occurring at the C-terminal of EBNA-1 may affect the functions of EBNA-1 protein, and consequently, affect DNA replication, transcription, or oncogenic potential EBV $[9,13]$. The sequence substitutions were frequently identified between residue 487 and 583 [14]. The two main mutant groups were identified and termed as prototype strains (similar to the prototype isolated from B95 cell line) and variant strains, which differed by 15 amino acids [14]. The further subtype identification 
was based on the amino acid at position $487[14,15]$. The EBV isolates could be divided into five subtypes: there are two prototype strains (P-strain) with either an alanine residue (termed as $\mathrm{P}$-Ala), or a threonine residue (termed as $\mathrm{P}$-Thr) at position 487, and three variant strains (V-strain) with either a leucine residue (termed as V-Leu), a valine residue (termed as V-Val) or a proline residue (termed as V-Pro) at this position [14,15]. These EBNA-1 subtypes display an association with geographical and human disease distribution. In these, V-Val is more frequent in NPC and almost detected in Chinese population, and preferentially exists in biopsies of NPC $[15,16]$.

Vietnam, located in Southern Asia, is well known for the high incidence and mortality rate of NPC in the world [17]. However, most studies on EBNA-1 subtype classification were limited to NPC in the Chinese, not in Vietnamese population. In our previous study, we established the protocol for genotyping of the EBNA-1 subtype from of nasopharyngeal biopsy samples collected from Vietnamese NPC patients, and the results suggested that the $\mathrm{V}$-Val subtype is the preferentially subtype associated with NPC [18]. In this current study, in order to explore the characteristics of the V-Val subtype in the Vietnamese population, we analyzed the polymorphisms of the $E B N A-1$ gene in EBV-associated NPC in the comparison to the prototype B95-8 strain.

\section{MATERIALS AND METHODS}

Ethics Statement. The Institutional Ethics Board approval, the decision number of the permission from Ethics committee: 516/BVCR-HDDD, was obtained from the Medical Ethics Committee of the Cho Ray Hospital, Ho Chi Minh City, Vietnam. All the biopsy samples used in current study were collected from participants, who agreed and signed all the consent forms.

Sample Collection and DNA Isolation. Fifty-eight NPC biopsy samples were collected from local patients at the Cho Ray Hospital, Ho Chi Minh City, Vietnam. All the sample were submitted to the histopathological diagnosis center to confirm the NPC diagnosis. Notably, all biopsies were collected from patients, who obeyed the ethical approval for study of human samples, and patients who agreed with the purpose of the study.

For DNA isolation, biopsies were lysed in lysis buffer, containing $10 \mathrm{mM}$ Tris-HCl pH 8, $10 \mathrm{mM}$ EDTA, $150 \mathrm{nM}$ $\mathrm{NaCl}, 2.0 \% \mathrm{SDS}$, and $0.1 \mathrm{mg} / \mathrm{mL}$ Proteinase $\mathrm{K}$, incubated overnight at $56^{\circ} \mathrm{C}$. Total of genomic DNA of clinical samples was extracted using a phenol/chloroform solution, $\mathrm{pH} 8$. The purification of DNA was done by a $99.0 \%$ ethanol solution. The quality and purity of DNA isolates were measured by the evaluation of $A_{260} / A_{280}$ proportion. The DNA solution was stored in Tris-EDTA $0.5 \mathrm{M}$, at $-20^{\circ} \mathrm{C}$ for further assays.

The PCR Amplification of EBNA-1 C-Terminal Domain of Clinical Samples and C-Terminal Domain Sequencing. Nested polymerase chain reaction (nestedPCR) was applied to amplify the C-terminal region of EBNA-1. The sequence and position of primers used in two stages of nested-PCR are shown in Table 1 and Figure 1, respectively. The EBNA-1-1 and EBNA-1-2 primers were used for stage 1 of nested-PCR, and EBNA-1-3 and EBNA-1-4 primers were used in stage 2 of nested-PCR. Both stages of nested-PCR were performed in a total of $15 \mu \mathrm{L}$, containing $100 \mathrm{ng}$ genomic DNA template (stage 1) or $100 \mathrm{ng}$ stage $1 \mathrm{PCR}$ product (stage 2), $0.5 \mu \mathrm{M}$ each primer, and 7.5 $\mu \mathrm{L}$ MyTaqTM Mix (Cat. No. BIO-25041; Bioline UK, London, UK).

Table 1. The sequence of primers used in two stages nested-PCR.

\begin{tabular}{|c|c|c|c|}
\hline Stage & Primers & Sequences & Temperature \\
\hline \multirow{2}{*}{1} & EBNA-1-1 & 5'-TAG TCA GTC ATC ATC ATC CG-3' & $55^{\circ} \mathrm{C}$ \\
& EBNA-1-2 & 5'-GGG ATT TAT TCT TTA GTG CG-3' & \multirow{2}{*}{$60^{\circ} \mathrm{C}$} \\
\hline \multirow{2}{*}{2} & EBNA-1-3 & 5'-GCC ATT TTT CCA CCC TGT AG-3' \\
\hline
\end{tabular}

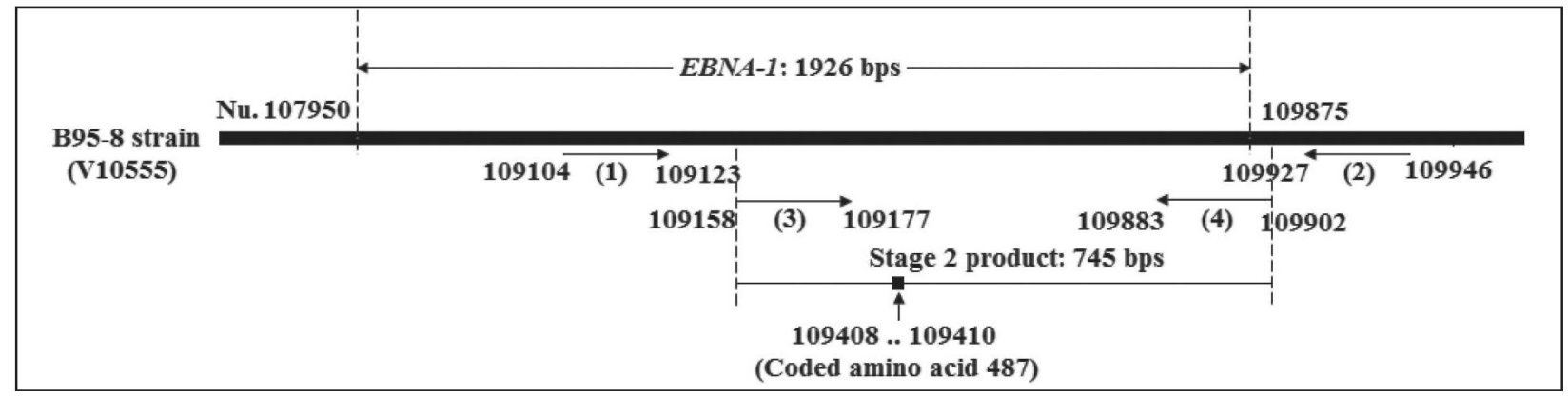

Figure 1. Schematic of the EBNA-1 gene and position of primers aligned with B95-8 strain (V10555). Primer 1: EBNA-1-1; primer 2: EBNA-1-2; primer 3: EBNA-1-3 and primer 4: EBNA-1-4. 
The PCR amplification was performed with an initial denaturation at $94{ }^{\circ} \mathrm{C}$ for $5 \mathrm{~min}$.; followed by 45 cycles of denaturation at $94{ }^{\circ} \mathrm{C}$ for 30 seconds, annealing at 55 ${ }^{\circ} \mathrm{C}$ (stage 1 ) or $65^{\circ} \mathrm{C}$ (stage 2) for 30 seconds, extension at $72{ }^{\circ} \mathrm{C}$ for 30 seconds; and elongation step at $72{ }^{\circ} \mathrm{C}$ for $10 \mathrm{~min}$. The nested-PCR products were visualized and analyzed by electrophoresis through stained with ethidium bromide, and 2.0\% agarose gel. For EBNA-1 C-terminal sequencing, $30 \mu \mathrm{L}$ products of the second stage of nestedPCR were sent to Nam Khoa Biotek Co. Ltd. (Ho Chi Minh City, Vietnam) for direct sequencing in both direction with primers EBNA-1-3 and EBNA-1-4.

Determination and Analysis of EBNA-1 V-Val Subtypes. The results of EBNA-1 C-terminal sequencing was read by Chromas 2.6.4 (Technelysium; https:// technelysium. com.au/wp/chromas/) and checked for sequencing homology using BLAST [National Center for Biotechnology Information (NCBI); https://www.ncbi. nlm.nih.gov]. For determination of EBNA-1 C-terminal subtypes, according to the study of Bhatia et al. [14] and Gutiérrez et al. [15], amino acid at position 487 was used as the signature residue for EBNA-1 subtypes. For the current study, the valine residue at position 487 , identified as V-Val subtype, was enrolled into the analysis of V-Val characteristics of Vietnamese NPC patients. All the V-Val subtype sequence data were compared with the P-Ala B958 strain (Genbank accession \#V10555). The alignment between data sequence and B95-8 strain sequence were analyzed using BioEdit (www.mbio.nesu.edu/BiolEdit/ bioedit.html) sequence alignment editor.

\section{RESULTS}

V-Val EBNA-1 Subtype was Preferential in Vietnamese Nasopharyngeal Cancer. The C-terminal domain of EBNA-1 was successfully amplified, observed in a dis-

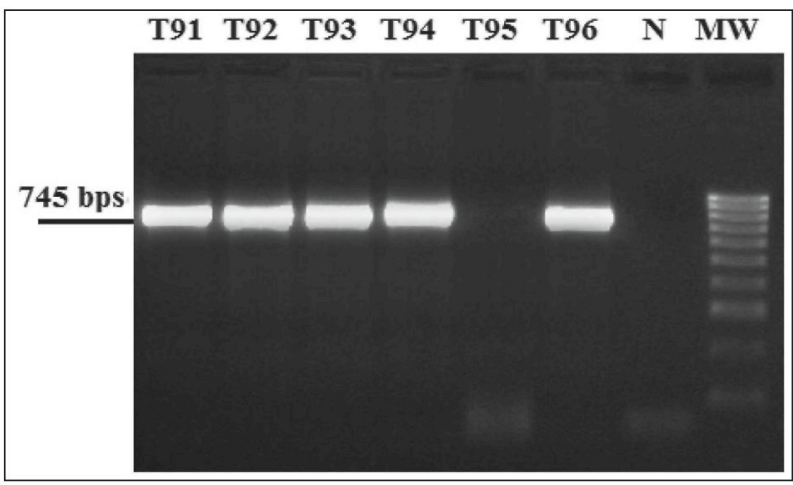

Figure 2. Electrophoresis of nested-PCR products of the represented NPC biopsy samples. T91, T92, T93, T94, T95, T96: clinical biopsy samples; N: negative control; MW: molecular weight $100 \mathrm{bp}$. tinct band with 745 bp (shown in Figure 2) and sequenced in 44 of 58 clinical samples, accounting for $75.86 \%$. The nucleotide variations were identified by comparison with the B95-8 P-Ala sequence. The sequencing results showed that P-Ala, P-Thr, V-Val and V-Leu were identified based on the amino acid at position 487 (Figure 3). The proportion of P-Ala, P-Thr, V-Val and V-Leu were two of 44 cases (accounting for $4.55 \%$ ), five of 44 cases (accounting for $11.36 \%$ ), 35 of 44 cases (accounting for $79.55 \%$ ) and two of 44 cases (accounting for $4.55 \%$ ), respectively. Thus, it was concluded that the V-Val EBNA-1 subtype was the common subtype, and V-Pro was not detected in Vietnamese nasopharyngeal cancer.

Characteristic of V-Val Sequence patterns of EBNA-1 in Vietnamese Nasopharyngeal Cancer. All the nucleotide variants of sequence, encoded the amino acid residue 487 of the EBNA-1 C-terminal domain, 35 cases of $\mathrm{V}$-Val EBNA-1 were determined by comparison with the B95-8 sequence. As a result, five patterns of VVal subtype ofEBNA-1 C-terminal domain, coded pattern 1 to pattern 5, were identified (Table 2). All of those five patterns contained seven consensus changes, including five amino acid changes and two silent changes (Figure 4). The five amino acid changes were at residue 487 (Ala $\rightarrow$ Val; GCT $>$ GTT), 499 (Asp $\rightarrow$ Glu; GAC $>$ GAG), $502(\mathrm{Thr} \rightarrow$ Asn; ACT >AAT), $524(\mathrm{Thr} \rightarrow$ Ile; ACT $>$ ATT $), 594(\mathrm{Arg} \rightarrow$ Lys; $\mathrm{A} G \mathrm{G}>\mathrm{A} A \mathrm{G}$ ). The two silent amino acid changes were at residue $520(\mathrm{Leu} \rightarrow \mathrm{Leu}$; $\mathrm{CT} A>\mathrm{CTC}$ ) and 553 (Pro $\rightarrow$ Pro; $\mathrm{CC} G>\mathrm{CC} A$ ). In the $\mathrm{V}$-Val subtype, pattern isolates showed two or more additional changes except for the consensus sequence changes (Figure 5). There were pattern 1: 17 of 35 isolates (accounting for $48.57 \%$, represented by T5) with additional amino changes at residue 528 (Ile $\rightarrow \mathrm{Val}$; $A$ TT>GTT), 533 (Leu $\rightarrow$ Ile; $C$ TT $>A T T$ ); pattern 2: 14 of 35 isolates (accounting for $40.00 \%$, represented by T6) with additional substitutions at residue 528 (Ile $\rightarrow$ Val; $A \mathrm{TT}>G \mathrm{TT}), 533$ (Leu $\rightarrow$ Ile; $C \mathrm{TT}>A \mathrm{TT}), 585(\mathrm{Thr} \rightarrow \mathrm{Ile}$; $\mathrm{ACA}>\mathrm{ATA}$ ); pattern 3: 2 of 35 isolates (accounting for $5.71 \%$, represented by $\mathrm{T} 77$ ) with additional changes at residue 529 (Pro $\rightarrow$ Gln; CCA $>$ CAA), 585 ( Thr $\rightarrow$ Ile; ACA $>$ ATA), 588 (Ala $\rightarrow$ Pro; GCT $>C C T$ ); pattern 4: one of 35 isolates (accounting for $2.86 \%$, represented by T70) with additional changes at amino acid 528 (Ile $\rightarrow$ Val; $A$ TT $>$ GTT), $533(\mathrm{Leu} \rightarrow$ Ile; $C \mathrm{TT}>A \mathrm{TT}), 585(\mathrm{Thr} \rightarrow \mathrm{Ile}$; ACA $>$ ATA), 588 (Ala $\rightarrow$ Pro; GCT $>$ CCT); pattern 4: one of 35 isolates (accounting for $2.86 \%$, represented by T75) with additional amino acid changes at position 492 (Ser $\rightarrow$ Cys; $A \mathrm{GT}>$ TGT), 528 (Ile $\rightarrow$ Val; $A$ TT $>$ GTT), 533 (Leu $\rightarrow$ Ile; $C \mathrm{TT}>A \mathrm{TT}), 585(\mathrm{Thr} \rightarrow \mathrm{Ile}$; ACA $>$ ATA $), 588(\mathrm{Ala} \rightarrow$ Pro; $G C T>C C T)$. Therefore, the common pattern of V-Val subtypes were pattern 1 (accounting for $48.57 \%$ ) and pattern 2 (accounting for $40.00 \%$ ). 


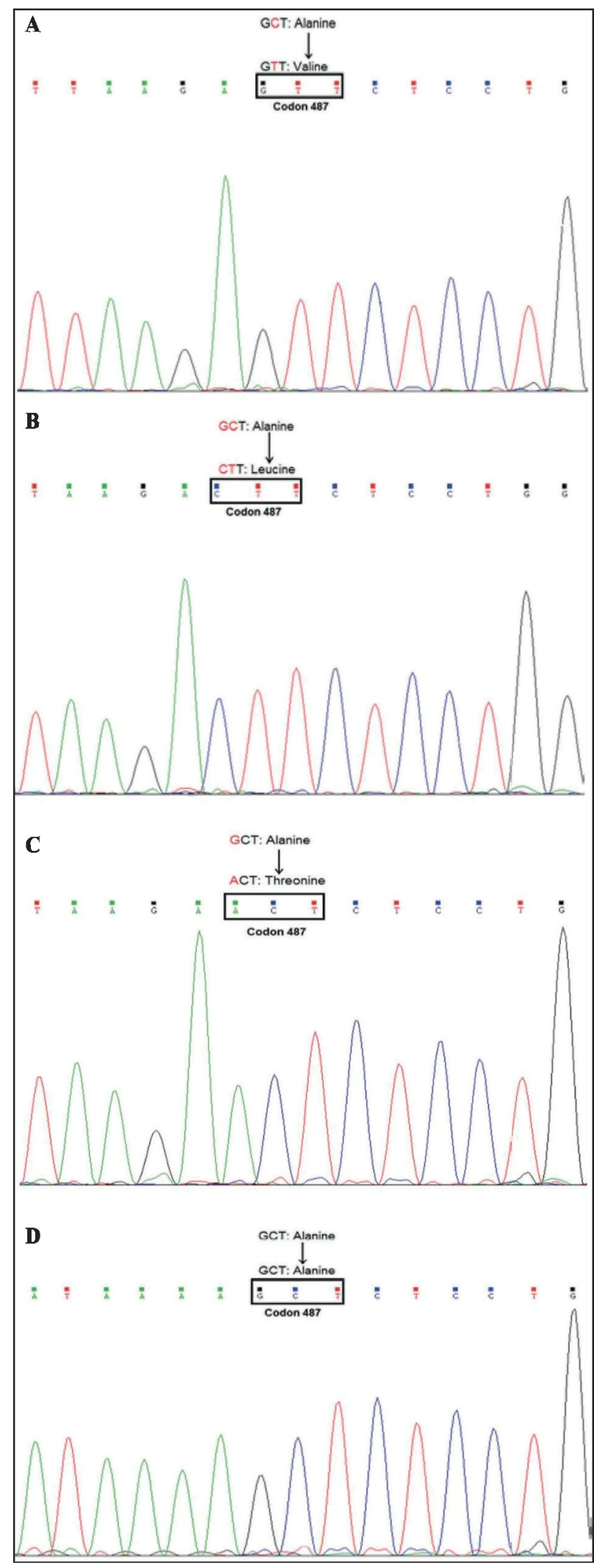

Figure 3. Represented sequence identification of EBNA-1 subtype based on the amino acid at position 487. A) T91: V-Val subtype; B) V-Leu subtype; C) P-Thr subtype; D) P-Ala subtype.
Novel Patterns of V-Val Subtype of the EBNA1 C-Terminal Domain from Vietnamese Patients. The previous study of Wang et al. [19] reported that the common pattern of EBNA-1 C-terminal domain contained 12 consensus sequence changes, including 10 amino acid changes at positions $487,499,502,524,528,533,594$, and two silent changes at residues 520 and 553 . Additionally, those 12 consensus sequence changes were reported to be the same as the sequences of published V-Val subtype or its sub-variants at the sequenced part in previous studies $[13,15,20-23]$. Compared to our study, 10 amino acid at positions $487,499,502,520,524,553$ and 594 were the same as the GC4 (Table 3). The amino acid at positions 528 and 533 were different to the consensus amino acid of the GC4 sequence. Moreover, besides the consensus substitutions, which were reported in GC4, in our patterns of EBNA-1 variants, the amino acid at position 492 (Ser $\rightarrow$ Cys) by T75, 528 (without change: Ile); 529 (Pro $\rightarrow$ Gln); 553 (with change: Leu) by T77; 585 (Thr $\rightarrow$ Ile) by T6, T77, T70, T75; and 588 (Ala $\rightarrow$ Pro) by T77, T70, T75, were different to GC4 (Table 3). Therefore, it could be concluded that pattern 1 (represented by T5) was the same as the GC4. Pattern 2 (represented by T6), pattern 3 (represented by T77), pattern 4 (represented by T70), and pattern 5 (represented by T75) were different to GC4, thus, identified as the novel patterns of EBNA-1 C-terminal domain in Vietnamese NPC.

\section{DISCUSSION}

In the current study, we characterized the variations of the C-terminal domain of EBNA-1 sequences in a total of 44 EBNA-1-positive samples collected from Vietnamese nasopharyngeal cancer patients. To the best of our knowledge, this is the largest study of EBNA-1 sequence identification on EBV infection in Vietnamese cases on the high incidence and mortality rate of NPC in the world.

In general, four EBNA-1 subtypes were designed as V-Val, P-Ala, P-Thr and V-Leu. These findings were similar to the research of Sun et al. [9] and showed that four subtypes of EBNA-1, except for V-Pro, were observed. It was related it to the geographically-associated EBNA-1 subtype distribution. Of these, V-Val, accounting for $79.55 \%$, was the predominant subtype in Vietnam, an Asian country, which is similar to that of previous studies in Asian countries, such as Hong Kong; Chinese population but different from Western countries $[9,15,16,20,23]$. The V-Val subtype was reported as the isolate-induced higher transcriptional activity than those of the B95-8 subtype [13]. Additionally, in the current study, the nucleotide variations were analyzed between the nucleotide regions from 109408 to 109731 , encoding the amino acid region from 487 to 594 . As a result, most of the substitu- 


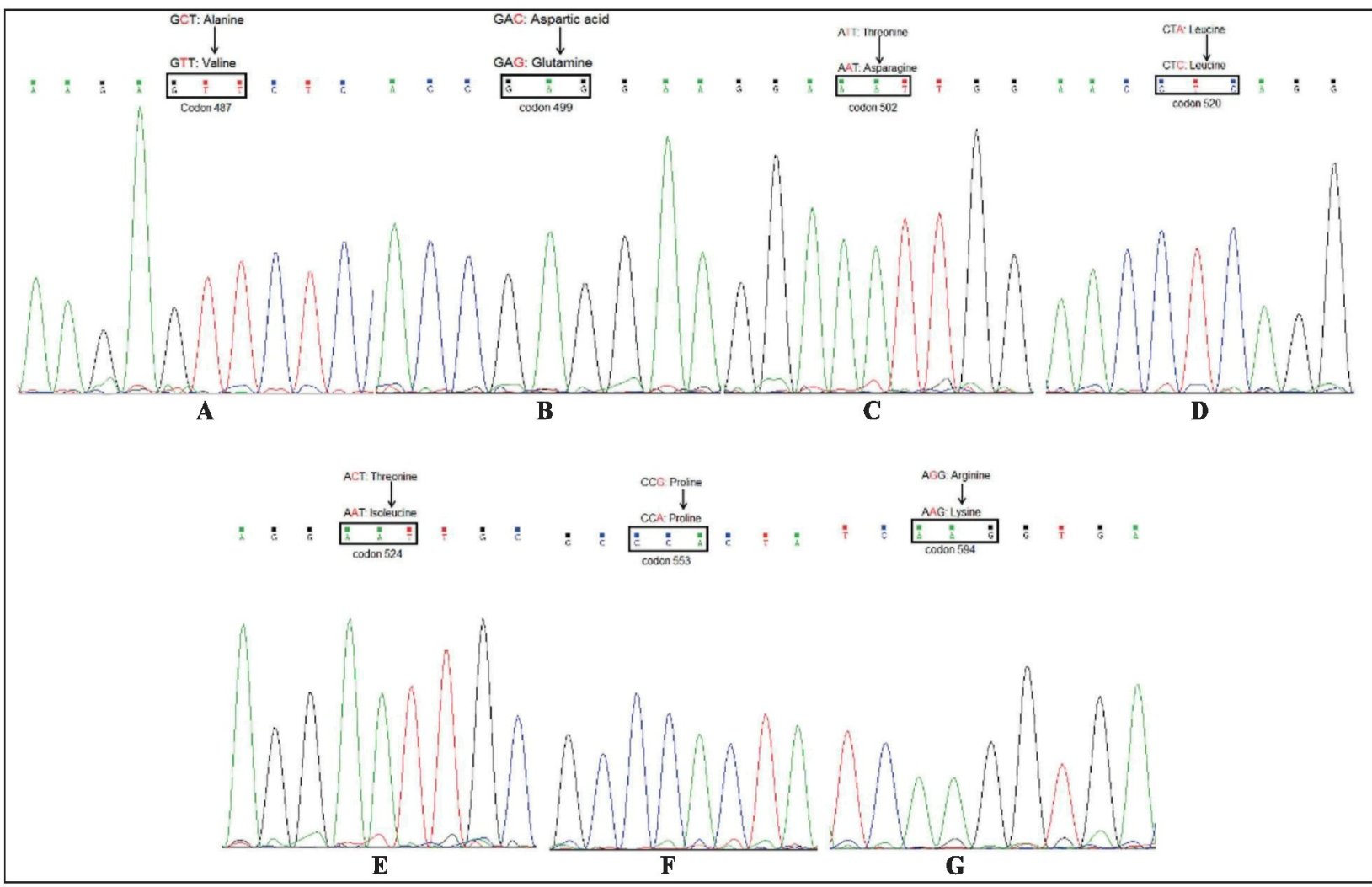

Figure 4. Represented nucleotide substitution consensus changes indicated by T5. Amino acid at position: A) codon 497; B) codon 499; C) codon 502; D) codon 520; E) codon 524; F) codon 553; G) codon 594.

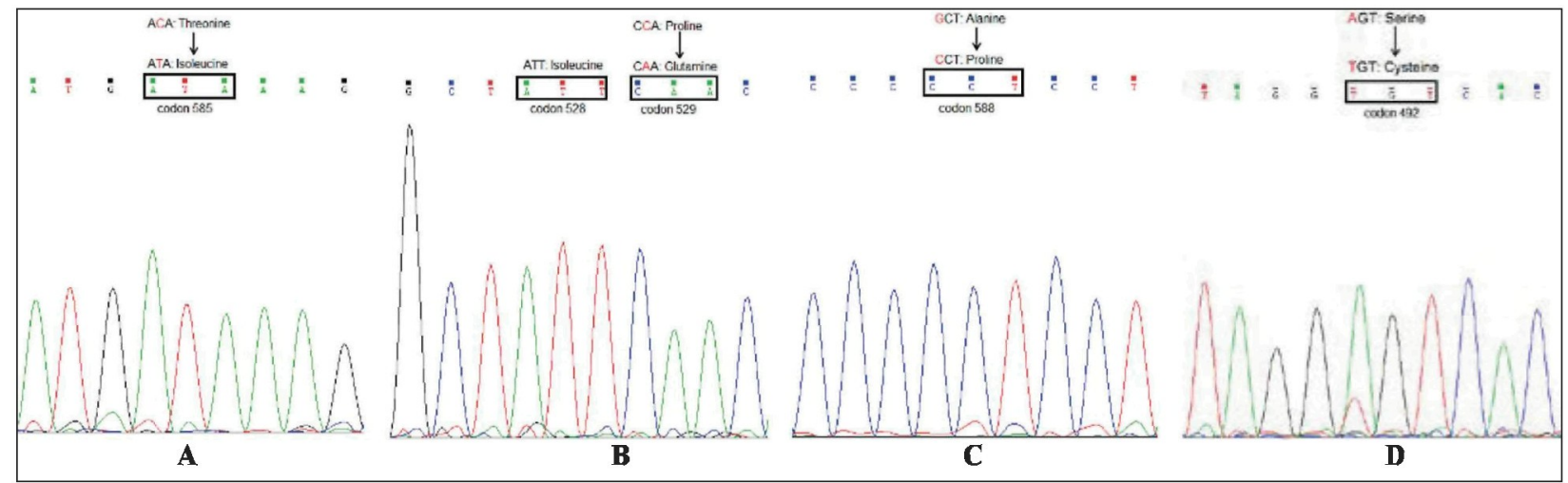

Figure 5. Represented nucleotide/amino acid additional changes: A) codon 585 by T6; B) codons 528 and 529 by T77; C) codon 588 by T77; D) codon 492 by T75.

tions were located on the function domain of EBNA-1 protein, including the dimerization domain, DNA binding domain and transactivation domain, subsequently affecting the function of EBNA-1 related to the viral replication, transcription, or enhancement of oncogenic potential EBV $[9,13]$. Moreover, the substitution of the amino acid at position $524(\mathrm{Thr} \rightarrow \mathrm{ll}$ ), led to the subsequent loss of a phosphorylation site in the V-Val subtype [16]. Taken together, the variations of amino acids in V-Val subtypes might be easier maintained at the stage of latent infection.
Given the amino changes at the C-terminal domain of EBNA-1, a total of five patterns were observed. Of these, four of five patterns, named as pattern 2, 3, 4 and 5, were identified as the novel patterns of the V-Val subtype of Vietnamese NPC patients. Notably, a mix of pattern 4 and novel pattern 5 of the V-Val EBNA-1 subtypes, shown in Figure 5(D), were observed. This observation was defined if double signals of base pairs occurred at nucleotide sequence residue 109423. Overall, four novel patterns were identified. However, whether these variations of the novel 
Table 2. Nucleotide and amino acid substitution in EBNA-1 C-terminal domain compared to B95-8B sequence.

\begin{tabular}{|c|c|c|c|c|c|c|c|c|c|c|c|c|c|c|c|c|c|c|c|c|c|}
\hline \multirow{4}{*}{ 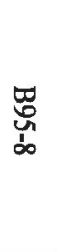 } & $\begin{array}{l}\text { 옹 } \\
\text { 客 }\end{array}$ & $\begin{array}{l}\overline{8} \\
8 \\
\end{array}$ & $\begin{array}{l}58 \\
\stackrel{8}{\circ} \\
\stackrel{5}{\circ}\end{array}$ & $\begin{array}{l}\overrightarrow{8} \\
\stackrel{8}{0}\end{array}$ & $\begin{array}{l}\overrightarrow{8} \\
\stackrel{8}{+}\end{array}$ & $\begin{array}{l}\text { 응 } \\
\text { 总 }\end{array}$ & $\stackrel{\overrightarrow{8}}{8}$ & $\begin{array}{l}\text { 응 } \\
\text { 点 }\end{array}$ & $\begin{array}{l}\text { 용 } \\
\text { 咅 }\end{array}$ & $\begin{array}{l}\text { 응 } \\
\text { 音 }\end{array}$ & $\underset{8}{\stackrel{8}{\circ}}$ & $\begin{array}{l}5 \\
\frac{8}{8}\end{array}$ & $\begin{array}{l}\overrightarrow{8} \\
\text { 岕 }\end{array}$ & $\begin{array}{l}\text { 응 } \\
\stackrel{8}{4} \\
+\end{array}$ & $\begin{array}{l}\text { 总 } \\
\text { 㞻 }\end{array}$ & 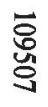 & ㄴㅇㅇ & 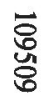 & 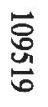 & $\begin{array}{l}\overline{8} \\
\text { 迨 }\end{array}$ & 兽 \\
\hline & \multicolumn{3}{|c|}{487} & \multicolumn{3}{|c|}{492} & \multicolumn{3}{|c|}{499} & \multicolumn{3}{|c|}{500} & \multicolumn{3}{|c|}{502} & \multicolumn{3}{|c|}{520} & \multicolumn{3}{|c|}{524} \\
\hline & $\mathrm{G}$ & C & $\mathrm{T}$ & A & G & $\mathrm{T}$ & G & A & C & G & A & A & A & C & $\mathrm{T}$ & C & $\mathrm{T}$ & A & A & C & $\mathrm{T}$ \\
\hline & \multicolumn{3}{|c|}{ Ala } & \multicolumn{3}{|c|}{ Ser } & \multicolumn{3}{|c|}{ Asp } & \multicolumn{3}{|c|}{ Glu } & \multicolumn{3}{|c|}{ Thr } & \multicolumn{3}{|c|}{ Leu } & \multicolumn{3}{|c|}{ Thr } \\
\hline \multirow{2}{*}{ T5 } & · & $\mathrm{T}$ & . & . & . & . & . & . & G & . & . & . & . & A & · & $\cdot$ & . & C & . & $\mathrm{T}$ & . \\
\hline & \multicolumn{3}{|c|}{ Val } & \multicolumn{3}{|c|}{ * } & \multicolumn{3}{|c|}{ Glu } & \multicolumn{3}{|c|}{ * } & \multicolumn{3}{|c|}{ Asn } & \multicolumn{3}{|c|}{+} & \multicolumn{3}{|c|}{ Ile } \\
\hline \multirow{2}{*}{ T6 } & $\cdot$ & $\mathrm{T}$ & $\cdot$ & . & . & . & . & $\cdot$ & G & . & · & . & . & A & · & . & $\cdot$ & C & . & $\mathrm{T}$ & . \\
\hline & & $\mathrm{Val}$ & & & * & & & Glu & & & * & & & Asn & & & + & & & Ile & \\
\hline & . & $\mathrm{T}$ & $\cdot$ & . & . & . & . & . & G & . & . & . & . & A & . & . & . & C & · & $\mathrm{T}$ & · \\
\hline 17 & & Val & 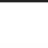 & & * & & & Glu & & & * & 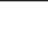 & & Asn & & & + & & & Ile & \\
\hline T70 & . & $\mathrm{T}$ & $\cdot$ & . & $\cdot$ & . & . & $\cdot$ & $\mathrm{G}$ & . & . & . & . & A & . & . & . & C & . & $\mathrm{T}$ & . \\
\hline $1 / 0$ & & Val & & & * & & & Glu & & & * & & & Asn & & & + & & & Ile & \\
\hline T75 & . & $\mathrm{T}$ & . & $\mathrm{T}$ & . & . & . & . & G & . & . & . & . & A & . & . & . & C & . & $\mathrm{T}$ & . \\
\hline $17 / 7$ & & $\mathrm{Val}$ & & & Cys & & & Glu & & & * & & & Asn & & & + & & & Ile & \\
\hline & 总 & 总 & 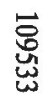 & 总 & 总 & 总 & $\begin{array}{l}\text { 总 } \\
\text { 范 }\end{array}$ & $\begin{array}{l}\text { 范 } \\
\text { 品 }\end{array}$ & $\begin{array}{c}\overrightarrow{8} \\
\text { 岕 } \\
\stackrel{\infty}{\infty}\end{array}$ & $\begin{array}{l}\text { 융 } \\
\text { \&ूे }\end{array}$ & 홍 & ㅎㅇㅇ & 홍 & $\begin{array}{l}\text { 홍 } \\
\text { 요 }\end{array}$ & $\begin{array}{l}\text { 유 } \\
\text { 융 }\end{array}$ & $\stackrel{8}{8}$ & $\underset{\mathrm{N}}{\stackrel{8}{0}}$ & $\underset{\mathrm{D}}{\mathrm{D}}$ & $\begin{array}{l}\text { 융 } \\
\text { స్ర }\end{array}$ & $\begin{array}{l}\text { 응 } \\
\text { ]్̈ }\end{array}$ & $\begin{array}{l}\vec{\circ} \\
\stackrel{\vec{\omega}}{\omega}\end{array}$ \\
\hline 品 & & 528 & & & 529 & & & 533 & & & 553 & & & 585 & & & 588 & & & 594 & \\
\hline & A & $\mathrm{T}$ & $\mathrm{T}$ & $\mathrm{C}$ & C & A & $\mathrm{C}$ & $\mathrm{T}$ & $\mathrm{T}$ & C & $\mathrm{C}$ & G & A & C & A & $\mathbf{G}$ & C & $\mathrm{T}$ & A & G & G \\
\hline & & Ile & & & Pro & & & Leu & & & Pro & & & $\mathrm{Thr}$ & & & Ala & & & Arg & \\
\hline $\mathrm{Tf}$ & $\mathrm{G}$ & . & . & . & . & . & A & . & . & - & . & A & . & . & - & . & . & - & . & A & . \\
\hline 10 & & $\mathrm{Val}$ & & & * & & & Ile & & & + & & & * & & & * & & & Lys & \\
\hline T6 & $\mathrm{G}$ & $\cdot$ & . & · & . & . & A & . & . & . & . & A & . & $\mathrm{T}$ & . & . & $\cdot$ & . & . & $\mathrm{A}$ & . \\
\hline 10 & & Val & 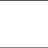 & & * & & & Ile & & & + & & & Ile & & & * & & & Lys & \\
\hline T77 & . & . & . & . & A & . & . & . & . & . & . & A & . & $\mathrm{T}$ & • & C & . & . & . & A & . \\
\hline $17 \pi$ & & $*$ & 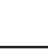 & & Gln & & & $*$ & & & + & & & Ile & & & Pro & & & Lys & \\
\hline$\pi$ & $\mathrm{G}$ & . & . & . & . & . & $\mathrm{A}$ & . & . & . & . & $A$ & . & $\mathrm{T}$ & . & C & . & . & . & $A$ & . \\
\hline 170 & & Val & & & * & & & Ile & & & + & & & Ile & & & Pro & & & Lys & \\
\hline T7 & G & . & . & . & . & . & A & $\cdot$ & . & . & . & A & . & $\mathrm{T}$ & . & $\mathrm{C}$ & $\cdot$ & . & . & A & . \\
\hline $1 / 7$ & & Val & & & * & & & Ile & & & + & & & Ile & & & Pro & & & Lys & \\
\hline
\end{tabular}

NB: The top four rows correspond to the nucleotide, amino acid position, nucleotide and amino acid of B95-8 prototype sequence. In each row, the upper character denoted the nucleotide that is different to the B95-8 prototype sequence. Conversely, the dot $(\cdot)$ denotes the same nucleotide compared to the referent sequence. The characters below indicate the amino acid written in the three letter code that is different to the reference sequence, while the asterisk $(*)$ indicates the unchanged amino acid, and the plus sign $(+)$ indicates the silent amino acid changes.

Table 3. The comparison between the patterns of the current study and the previous sequences.

\begin{tabular}{|c|c|c|c|c|c|c|c|c|c|c|c|c|c|c|}
\hline \multicolumn{2}{|c|}{ Codon } & $\mathbf{4 8 7}$ & $\mathbf{4 9 2}$ & $\mathbf{4 9 9}$ & $\mathbf{5 0 2}$ & $\mathbf{5 2 0}$ & $\mathbf{5 2 4}$ & $\mathbf{5 2 8}$ & $\mathbf{5 2 9}$ & $\mathbf{5 3 3}$ & $\mathbf{5 5 3}$ & $\mathbf{5 8 5}$ & $\mathbf{5 8 8}$ & $\mathbf{5 9 4}$ \\
\hline Pattern 1 & T5 & Val & Ser & Glu & Asn & Leu & Ile & Val & Pro & Ile & Pro & Thr & Ala & Lys \\
\hline Pattern 2 & T6 & $\cdot$ & $\cdot$ & $\cdot$ & $\cdot$ & $\cdot$ & $\cdot$ & $\cdot$ & $\cdot$ & $\cdot$ & $\cdot$ & Ile & $\cdot$ & $\cdot$ \\
\hline Pattern 3 & T77 & $\cdot$ & $\cdot$ & $\cdot$ & $\cdot$ & $\cdot$ & $\cdot$ & Ile & Gln & Leu & $\cdot$ & Ile & Pro & $\cdot$ \\
\hline Pattern 4 & T70 & $\cdot$ & $\cdot$ & $\cdot$ & $\cdot$ & $\cdot$ & $\cdot$ & $\cdot$ & $\cdot$ & $\cdot$ & $\cdot$ & Ile & Pro & $\cdot$ \\
\hline Pattern 5 & T75 & $\cdot$ & $\cdot /$ Cys & $\cdot$ & $\cdot$ & $\cdot$ & $\cdot$ & $\cdot$ & $\cdot$ & $\cdot$ & $\cdot$ & Ile & Pro & $\cdot$ \\
\hline Study 1 & GC4 & $\cdot$ & $\cdot$ & $\cdot$ & $\cdot$ & $\cdot$ & $\cdot$ & $\cdot$ & $\cdot$ & $\cdot$ & $\cdot$ & $\cdot$ & $\cdot$ & $\cdot$ \\
\hline \multicolumn{2}{|c|}{ Study 2 } & $\cdot$ & $\cdot$ & $\cdot$ & Thr & $\cdot$ & $\cdot$ & $\cdot$ & $\cdot$ & $\cdot$ & $\cdot$ & $\cdot$ & $\cdot$ & $\cdot$ \\
\hline
\end{tabular}

NB: The EBNA-1 sequence variants in study 1 [19] and study 2 [16]. The dot (·) denotes the same nucleotide compared to each of the sequences. 
V-Val patterns could affect the function of the EBNA-1 protein is uncertain and needs to be further investigated.

Conclusions. In summary, four EBNA-1 subtypes, including V-Val, P-Ala, P-Thr and V-Leu, were identified in 44 of 58 clinical nasopharyngeal biopsy samples, accounting for $75.86 \%$, based on the amino acid at position 487. Of these, the V-Val subtype, accounting for $79.55 \%$, was the preferential subtype in biopsies of NPC. The profile of $\mathrm{V}$-Val subtypes were completely analyzed by sequencing, aligned and compared to the B95-8 prototype sequence (accession \#V10555). As a result, five patterns of V-Val subtypes, containing seven consensus changes, including five amino acid changes at positions 487, 499, 502, 524 and 594 and two silent changes at residues 520 and 553, were observed. Notably, four of five patterns, including patterns $2,3,4$ and 5, were identified as the novel patterns of the V-Val subtype, showed the different changes of amino acid at positions $492,528,529,553,585$ and 588, by comparison with previous studies of V-Val EBNA-1.

\section{ACKNOWLEDGMENTS}

We wish to express our thanks to the research project sponsored by Ho Chi Minh City Open University. We thank all the recruited participants in this study and Dr. Nguyen Trong Minh, Dr. Nguyen Huu Dung, and all the staff members of Otorhinolaryngology at the Cho Ray Hospital, Ho Chi Minh City, Vietnam, for collecting the samples used in these studies.

Declaration of Interest. The authors report no conflicts of interest. The authors alone are responsible for the content and writing of this article.

\section{REFERENCES}

1. Epstein MA, Achong BG, Barr YM. Virus particles in cultured lymphoblasts from Burkitt's lymphoma. Lancet. 1964; 1(7335): 702-703.

2. zur Hausen H, Schulte-Holthausen H, Klein G, Henle W, Henle G, Clifford P, et al. EBV DNA in biopsies of Burkitt tumours and anaplastic carcinomas of the nasopharynx. Nature. 1970; 228(5276): 1056-1058.

3. Young LS, Murray PG. Epstein-Barr virus and oncogenesis: From latent genes to tumours. Oncogene. 2003; 22(33): 5108-5121.

4. Thompson MP, Kurzrock R. Epstein-Barr virus and cancer. Clin Cancer Res. 2004; 10(3): 803-821.

5. Saha A, Robertson ES. Epstein-Barr virus-associated B-cell lymphomas: Pathogenesis and clinical outcomes. Clin Cancer Res. 2011; 17(10): 3056-3063.
6. Tsurumi T, Fujita M, Kudoh A. Latent and lytic Epstein-Barr virus replication strategies. Rev Med Virol. 2005; 15(1): 3-15.

7. Chao M, Wang HN, Lu YJ, Chang YS, Yu JS. The V-val subtype Epstein-Barr virus nuclear antigen 1 promotes cell survival after serum withdrawal. Oncol Rep. 2015; 33(2): 958-966.

8. Kang MS, Kieff E. Epstein-Barr virus latent genes. Exp Mol Med. 2015; 47(2); e131.

9. Sun L, Zhao Z, Liu S, Liu X, Sun Z, Luo B. Sequence variation analysis of Epstein-Barr virus nuclear antigen 1 gene in the virus associated lymphomas of Northern China. PLoS One. 2015; 10(10): e0140529.

10. Ambinder RF, Mullen MA, Chang YN, Hayward GS, Hayward SD. Functional domains of Epstein-Barr virus nuclear antigen EBNA-1. J Virol. 1991; 65(3): 1466-1478.

11. Goldsmith K, Bendell L, Frappier L. Identification of EBNA1 amino acid sequences required for the interaction of the functional elements of the Epstein-Barr virus latent origin of DNA replication. J Virol. 1993; 67(6): 3418-3426.

12. Frappier L, O'Donnell M. Overproduction, purification, and characterization of EBNA1, the origin binding protein of Epstein-Barr virus. J Biol Chem. 1991; 266(12): 7819-7826.

13. Do NV, Ingemar E, Phi PT, Jenny A, Chinh TT, Zeng Y, et al. A major EBNA1 variant from Asian EBV isolates shows enhanced transcriptional activity compared to prototype B95.8. Virus Res. 2008; 132(1-2): 15-24.

14. Bhatia K, Raj A, Guitierrez MI, Judde JG, Spangler $\mathrm{G}$, Venkatesh $\mathrm{H}$, et al. Variation in the sequence of Epstein Barr virus nuclear antigen 1 in normal peripheral blood lymphocytes and in Burkitt's lymphomas. Oncogene. 1996; 13(1): 177-181.

15. Gutiérrez MI, Raj A, Spangler G, Sharma A, Hussain A, Judde JG, et al. Sequence variations in EBNA-1 may dictate restriction of tissue distribution of Epstein-Barr virus in normal and tumour cells. J Gen Virol. 1997; 78 (Pt 7): 1663-1670.

16. Zhang XS, Wang HH, Hu LF, Li A, Zhang RH, Mai $\mathrm{HQ}$, et al. V-val subtype of Epstein-Barr virus nuclear antigen 1 preferentially exists in biopsies of nasopharyngeal carcinoma. Cancer Lett. 2004; 211(1): 11-18.

17. Mahdavifar N, Ghoncheh M, Mohammadian-Hafshejani A, Khosravi B, Salehiniya H. Epidemiology and inequality in the incidence and mortality of nasopharynx cancer in Asia. Osong Public Health Res Perspect. 2016; 7(6): 360-372. 
18. Lao TD, Phuong TK, LE TAH. Study of Epstein-Barr virus nuclear antigen (EBNA-1) variations: V-val type preferentially exists in biopsies of nasopharyngeal carcinoma from Vietnamese patients. Iran J Ped Hematol Oncol. 2018; 8(2): 75-86.

19. Wang Y, Liu X, Xing X, Cui Y, Zhao C, Luo B. Variations of Epstein-Barr virus nuclear antigen 1 gene in gastric carcinomas and nasopharyngeal carcinomas from Northern China. Virus Res. 2010; 147(2): 258264.

20. Chen YY, Chang KL, Chen WG, Shibata D, Hayashi $\mathrm{K}$, Weiss LM. Epstein-Barr virus-associated nuclear antigen-1 carboxy-terminal gene sequences in Japanese and American patients with gastric carcinoma. Lab Invest. 1998; 78(7): 877-882.
21. Sandvej K, Zhou XG, Hamilton-Dutoit S. EBNA-1 sequence variation in Danish and Chinese EBV-associated tumours: Evidence for geographical polymorphism but not for tumour-specific subtype restriction. J Pathol. 2000; 191(2): 127-131.

22. Snudden DK, Smith PR, Lai D, Ng MH, Griffin BE. Alterations in the structure of the EBV nuclear antigen, EBNA1, in epithelial cell tumours. Oncogene. 1995; 10(8): 1545-1552.

23. Wang WY, Chien YC, Jan JS, Chueh CM, Lin JC. Consistent sequence variation of Epstein-Barr virus nuclear antigen 1 in primary tumor and peripheral blood cells of patients with nasopharyngeal carcinoma. Clin Cancer Res. 2002; 8(8): 2586-2590. 